\title{
Analysing Social Needs of the Ukrainian Ex-Combatants: Looking on The Lived Experience
}

\section{Tetyana Semigina ${ }^{1}$, Anna Kachmaryk ${ }^{2}$, Olena Karagodina ${ }^{1}$}

\author{
${ }^{1}$ Academy of Labour, Social Relations and Tourism \\ 3-A Kiltseva Doroha, Kyiv, 03187, Ukraine \\ 2 Ukrainian Catholic University \\ I. Svientsitskoho Street, 17, Lviv, 79011, Ukraine
}

DOI: $10.22178 /$ pos. $71-4$

JEL Classification: 139

Received 28.05.2021

Accepted 28.06.2021

Published online 30.06.2021

Corresponding Author:

Tetyana Semigina

Semigina.tv@socosvita.kiev.ua

(c) 2021 The Authors. This article is licensed under a Creative Commons Attribution 4.0 License (c) (1)

Abstract. Since 2014, Ukraine experiences armed conflict on the territory of its eastern
part. The Ukrainian government had announced the anti-terrorist operation (ATO) to
combat the separatists. This paper reports on research exploring the social needs of
ex-combatants in Ukraine and pathways for social reintegration available to them. The
research data reached theoretical saturation by interviewing ten ex-combatants and 11
representatives of different services (social workers, psychologists, psychotherapists,
priests etc.). Additionally, field notes and grey literature were also considered for the
analysis. To triangle, the data received from an interview the analysis of national legal
acts on social protection of ex-combatants were analysed.

The following emerging themes came from the study: 1) expectations vs ambivalent attitudes and needs; 2) needs in social workers vs lack of social services. First, the study demonstrates that the primary need of the ATO (OOS) participant after returning home is social and psychological support. ATO participants say they have high expectations for the family and society, not from the state. However, some of the excombatants face ambivalent and hostile attitudes.

Conducted interviews reveal that social support to ATO veterans is reduced mainly to material benefits: privileges, subsidies, cash payments, etc. There is still no single model of social support for ATO participants that is legally defined. In addition, there is no prescribed standardised mechanism for providing social services to combatants.

The Ukrainian legislation includes several acts related to providing various benefits and guarantees of social protection for veterans. However, the ex-combatants stated that they filled unprotected. Opportunities for employment, education and good quality of life overall without the support promised by the legislation was rather tricky. Data suggest that transition to civilian life for ex-combatants is undermined by inadequate procedures, lack of support, and complicated administrative demands.

Based on the study findings, the recommendations to amend the state program of physical, medical, psychological rehabilitation and re-adaptation of ATO participants were proposed. The changes to the program might include the introduction of social and psychological support to be provided by all centres and services for ATO veterans. Furthermore, social participation and inclusion of ex-combatants concerning the DDR (Disarmament -Demobilisation and Reintegration) concept and resilience-based approach should be a core idea of social work approach instead of paternalistic social welfare approaches inherited by Ukraine from the Soviet model of social assistance.

The findings indicate pitfalls in the protective framework of war veterans. Currently, the available social support comes down to material benefits: benefits, subsidies, cash payments and more. Respondents point out the need to develop comprehensive social work interventions for combatants. This paper concludes that more needs to be done to enhance the social services for the new group of social work clients, including services that could enable ex-combatants to develop the skills they need to reintegrate within their community.

Keywords: armed conflict aftermath; ex-combatant; social needs; reintegration; social work; protection frameworks. 


\section{INTRODUCTION}

The number of people affected by humanitarian crises and conflicts has almost doubled over the past decade and is expected to keep rising [27]. Therefore, the international organisations [11] suggested implementing the so-called DDR concept in the conflict and post-conflict areas (Disarmament - Demobilisation - Reintegration).

Reintegration requires the involvement of social workers. According to V. Terziev [26], the essence of the social work with servicepersons discharged from military service and the members of their families during the transition period lies in the social adaptation of this category of the population to the new conditions of life in a civil environment, in a specific social medium, which is implemented in the following stages: preparation, entry, adaptation and development.

The review of recent research (M. Brickell, M. Russell and R. Smith [2]; M. Crock, N. Hart and R. McCallum [4]; K. Lamichhane [14]) reveals that the voices, concerns and pathways for the reintegration of ex-combatants are underresearched, as well as the adequacy of existing DDR processes and protection frameworks. The realities faced by ex-combatants, especially those with disabilities resulting from the armed conflict, need to become more visible in a nationally recognised post-conflict agenda. This requires a re-evaluation of the relevance of social policies on ex-combatants. Ukraine is not an exemption from this realm.

Since 2014, Ukraine experiences armed conflict on the territory of its eastern part. The nature of the conflict is a political one, related to the complicated relations with the bordering country (Russia) that supports separatist forces from the self-proclaimed "republics". The Ukrainian government had announced the anti-terrorist operation (ATO) to combat the separatists. Counterinsurgency forces of Ukraine consist of professional military forces and volunteer battalions. The researchers V. Horbulin [10], T. Semigina [22] pointed out the hybrid nature of this war, as the marital law have not been announced and the essence of conflict is obscure for many country outsiders, ambivalent to many insiders and somewhat complicated. The hybrid war has various dimensions, including military, political, economic, social, humanitarian, and informational, affecting the perception of the war participants and their communities.
As of mid-2019, according to the Ministry of Veterans Affairs, Temporarily Occupied Territories and Internally Displaced Persons of Ukraine [16], there were approximately 370,000 veterans of ATO who have been registered as war combatants.

It is worth mentioning the increasing numbers of Ukrainians (enlisted, conscripted, volunteers) returning home from battlefields face challenges in reintegrating back into their communities [30] and discrimination [12].

The object of the research - social needs of excombatants in Ukraine and pathways for social reintegration available to them. We also look at the protection frameworks for the veterans of ATO build up by 2020 .

The research explores ex-combatants main life problems and needs after their demobilisation and identifies their social support expectations. Based on findings, we discussed how to move from a concept of the protection frameworks predominantly focused on "assistance" to a predominantly focused on meeting their real needs and provide recommendations for amending the state target program of social support for ATO participants in the process of adaptation to peaceful life and reconsidering the protective framework.

\section{METHODOLOGY}

Phenomenology as ontology and epistemology was selected as a theoretical framework for our research because the primary focus for hermeneutic phenomenological inquiry is lived experience of the everyday world. Such experience presents to the individual the many truths and realities of life. Through accessing lived experience, researchers may understand the meanings and perceptions of another person's world [19]. This requires attentiveness to how language is used, an awareness of life as an interpretive experience, and an interest in the human meaning and how we make sense of our lives [15].

An exploratory phenomenological study was selected as the most appropriate research design to portray the lived experiences of Ukrainian excombatants, given the challenges in studying a phenomenon whose limits cannot be clearly defined.

The data were analysed using modified Colaizzi's content analysis method $[7 ; 18]$. The extension to 
Colaizzi's analysis method allows participants to express their experiences in the narrative indepth interviews through everyday language. Formulated meanings were organised into themes that were further integrated into a detailed description. The essential structure of social support to ex-combatants was formulated and further discussed with the participants.

So, phenomenology was applied both as a philosophy and a research method that helps illuminate ex-combatants experiences. The main focus of our interpretative and 'participant oriented research approach was on human experience, implicit and explicit meanings embedded in participants' descriptions. It is comprised of veterans' self-assessments of their reintegration and life situations, as well as meanings of such situations provided by professionals involved in social support networks, as well as access to social support on the community level, readiness to serve for community programmes etc.

The data of interviews were audio-recorded and transcribed verbatim before thematic analysis was applied, working inductively with the transcripts. Additionally, field notes and grey literature (reports of the social services for excombatans in Lviv and Dnipro) were also considered for the analysis. Finally, to triangle, the data received from an interview analysing national legal acts on social protection of ex-combatants were analysed.

This paper presents an overview of the following emerging themes from the study: i) expectations vs ambivalent attitudes and needs; ii) needs in social workers vs lack of social services. Quotes from participants will be presented throughout: ex-combatants will be referred to as 'excombatant, whereas representatives of different services will be referred to as 'participants'. No further personal or professional details will be included, as, given the specificity of the topic, it might lead to the identification of the participants.

The research was conducted in NovemberDecember 2019. Data from a purposive sample reached theoretical saturation by interviewing ten ex-combatants and 11 representatives of different services (social workers, psychologists, psychotherapists, priests, etc.). Ex-combatants were aged 25-35 years, nine men and one woman, half of them were former regular military staff, half - volunteers who went to the army to defend Ukraine. They served in ATO in 2014-
2015 or $2015-2017$, so they experience adjusting to a peaceful life.

Each of the participants invited to the research study was informed of their rights; full disclosure of the intent and reason for the research study had been provided for all participants.

\section{RESULTS}

\section{Theme 1: expectations vs ambivalent attitudes and needs}

During interviews, ex-combatants shared their mainly negative experience of adjusting to a peaceful life, described their unmet needs and hopes.

In times of demobilisation, combatants have certain expectations from the state, society and family. Each of the interviewed ex-combatants emphasised that material benefits were not a priority when returning home, although financial support was equally important to the military. Upon returning home, the primary need of the ATO veterans was social and psychological support:

"No apartments, no money, I did not expect anything from the state" (Ex-combatant).

"Everyone talked about social and psychological support, benefits and high pay. Actually, what I expected from the state is social and psychological support" (Ex-combatant).

"Many talked about benefits and subsidies, apartments, land, cash payments. The state declares support, social guarantees. And some payments are not supported" (Ex-combatant).

The majority of respondents (7 out of 10 excombatants) said they had high expectations from the family and society. They hoped for understanding among the people living next to them: a spouse, children, family, friends, neighbours and co-workers:

"I expected the least support and understanding from family and friends. And now, I very much feel the need for society to appreciate the actions of combatant" (Ex-combatant).

"My mom and my ex-girlfriend supported me like no other. Without their support, I don't know what would happen to me. I am very grateful to them" (Ex-combatant).

"My family has helped me a lot. I expected a change from society: to increase the level of dignity 
every time. But today's events upset me. People make the same mistakes" (Ex-combatant).

Half of interviewed ATO veterans claim that personal attitudes had changed during the service and form a different type of relationship:

"We couldn't have been together with our exgirlfriend. However, the passage of military service has cast a touch on the relationship. During the service in ATO, support was quite strong. But the result is quite expected and very common. After a long emotional and physical strain, people change their behaviour. Exit one: either to put up and wait or to go" (Ex-combatant).

"I did not expect this attitude of people towards you just because you are a participant in the war. He did not expect the pity that can now be felt; did not think that the veterans of the ATO (OOS) would begin to be interpreted as an aggressive person" (Ex-combatant).

Regarding the basic needs of ex-combatants, we can conditionally divide them into individual and everyday needs. However, it is worth bearing in mind that each ATO veteran has acquired particular experience in combat operations. This experience differs depending on the length of stay in the ATO zone, psychological (physical) injuries, etc. For example:

"The issue of needs is, for the most part, an individual one. But there are needs that unite all participants in the Russo-Ukrainian War" (Excombatant).

However, there are also some everyday situations that all ATO veterans interviewed during the study mentioned:

"When you get home, you need help. But you are waiting for a runner, papers, documents. All this is much more complicated. Lack of elementary respect for your action" (Ex-combatant).

8 out of 10 interviewed combatants themselves stress the respect and appreciation for their activities, understanding of veterans' experience, attention to needs as the necessary components of their protective frameworks in the period of returning home:

"A combatant even needs people to remember and understand that there is a war going on. But no. Here quietly and in the news, daily reports of human casualties at the front, which is already an "abnormal norm" (Ex-combatant).
Suppose such values as respect, understanding, and gratitude are not felt by the ATO veteran. In that case, the process of reintegration and adaptation to a peaceful life becomes more difficult each time. This can affect communication with family, friends, former colleagues. All representatives of different services had pointed this out:

"There are times when a veteran and their family are unable to resolve the difficulties themselves. Complex adaptation process: a certain indifference on the part of the community about the war, previous place of work, change of family relations, etc. It is difficult for an ATO participant to say that he has real difficulties and needs help" (Participant).

"When we speak about social support from the society, it should be said that there should be a socalled "social contract". It must be understood that a serviceman performs their duties on the frontline; others must perform their functions in the rear. This is a normal distribution of responsibilities. Society must understand that a soldier has abandoned humanity for the sake of the humanity of others" (Participant).

In interviews, respondents discussed that psychological trauma, stress, post-traumatic stress disorder, flashback, addiction to war, injury, disability, complex adaptation, conflicts with family - all of these consequences could lead to asocial behaviour of ex-combatants. As a result, there could be uncontrolled aggression, alcoholism, drug addiction, and offences. During the interviews, respondents mention that the number of suicide committed by ATO ex-combatants because of PTSD is unknown since no one records them.

The other research conducted in Ukraine also reveals that the military personnel and their families experience many reintegration problems. Authors 0. Kharchenko and 0. Mramornova [13] presented findings that for many ATO participants, their adaption to civil life accompanied by severe feelings of the collapse of prospects, isolation and alienation from public life because, in real life, their military experience and knowledge are often unclaimed. Z. Boyarska and R. Pinchuk [1] demonstrate that nearly all ATO participants have problems understanding their own families and the community. They also feel fear and suspicions, demonstrate aggressive behaviour, have high risks to become alcohol or drug-addicted.

So, ex-combatants have broad social and psychological needs. Some of these problems are com- 
mon to any militants that had battlefield experience (see, for example, research of [17, 29]), while others could be associated with the challenging nature of the armed conflict on the territory of Ukraine and ambivalent perception of this 'hybrid war'.

\section{Theme 2: Needs in social workers vs lack of social services}

The Ukrainian legislation includes several acts related to providing various benefits and guarantees of social protection for veterans.

In particular, the Law of Ukraine "On Status of War Veterans, Guarantees of Their Social Protection" (dated 1993 and amended in 2018) is considered to be the most comprehensive legislation in this field [20]. The law provides benefits to combatants and persons equated to them (Article 12), persons with disabilities as a result of the war (Article 13), war participants (Article 14), persons who have special merits before the Motherland (Article 16), victims of the Revolution of Dignity (Article 161). In addition, according to the law, veterans are entitled to different social benefits covering, among other things, priority provision of housing land plots, loans for housing construction, discounts on payments for housing and utility services, free public transport, and provision of various health-care services. The concept of these social benefits Ukraine had inherited from the Soviet model of social assistance (where no social work or psycho-social support existed).

In 2016-2018, the Government of Ukraine had adopted a few acts, including the state program on rehabilitation, social and professional readaptation of ATO participants. The program includes medical, physical and psychological rehabilitation and social and professional readaptation for these individuals [5]. So, formally the legal protective frameworks for excombatants looks comprehensive. However, in 2019-2020, with political changes in the country and new government, no new regulations were adopted, the issue of social protection of excombatants became 'invisible'.

Conducted interviews reveal that social support to ATO veterans is reduced mainly to material benefits: privileges, subsidies, cash payments, etc. There is still no single model of social support for ATO participants that is legally defined. In addition, there is no prescribed standardised mecha- nism for providing social services to combatants. The analysis of the activities of the Lviv Center for Services to the Participants of the Fighting Activities and the Center for Assistance to the ATO Participants and their Families (Dnipro) suggests that there is a lack of quality indicators of service delivery since only quantitative indicators of work are established in their reports.

The interviewed respondents named peer-topeer support as a critical enabler for the social inclusion of former combatants. The stories provided by ex-combatants allow stating that peers' organisations are started to emerge as grassroots community initiatives. However, there is a question regarding their capabilities to provide adequate services.

At the same time, none of the respondents (ATO veterans) could meet and talk with the social worker in person. Answering the question: "Do you know the participants of the combat who needed social and psychological help but did not ask for it" the respondents say:

"There are many such brothers. Some offered help, and they successfully underwent psychological rehabilitation. Others sought help from specialists. Others were afraid or simply unwilling to admit it. They did not seek social and psychological support because they thought they were strong in spirit and could overcome everything independently. And so not everyone succeeds" (Ex-combatant).

"I know those who needed but did not turn. I know those who needed and didn't help. I know those in need who understood this, but the attitude towards psychologists and social workers is stereotyped. Nobody wants you to be thought of: returned from the front by a "psycho." Yet, here they do not turn" (Ex-combatant).

Mental health services based on the multidisciplinary approach are deficient. Furthermore, if persons apply to mental health hospitals, they might experience stigmatisation and even legal discrimination, such as further employment or obtaining a driver license.

During the interviews, participants stated that they filled unprotected. Opportunities for employment, education and good quality of life overall without the support promised by the legislation was difficult, if possible, at all. Moreover, high levels of unemployment and the country's political polarisation play a crucial role in the unstable positions of ex-combatants. And this reality has consequences: 
"After returning home, the ATO participant could not find a job. So yes, the way out is either going abroad to earn money or return to service. Thus the ATO zone is no longer a defence of the Motherland but an opportunity to earn money. As a result, we are losing the able-bodied population, and on the other hand, people are losing their sense of security" (Respondent).

Both experts and ex-combatants themselves believe that support from a social worker and a psychologist should be obtained:

"A combatant returning to a peaceful life must first adapt to a psychologist in a rehabilitation centre and seek the advice of a specialist in the social field" (Participant).

"Every ATO participant should receive services after they return home because there are difficult stages of adaptation. We are talking about the whole package of services provided by the stateorganised service delivery process" (Participant).

The collaboration could be in different ways, but the main thing is a meeting in person. Not short phone calls. It is crucial for a social worker and/or psychologist to meet a combatant who has just returned from the frontline. This meeting should discuss such essential issues as basic needs: social adaptation to a peaceful life; psychological assistance for processing the experience gained; legal advice on benefits, subsidies and cash payments; information directory of state institutions, non-governmental organisations, charitable foundations, rehabilitation centres, that is, a list of institutions where a combatant and his family will be able to receive quality services by the current legislation.

Yet, analysis of the interviews with excombatants proves that a culture of collaboration with a social worker and a psychologist has not been formed in Ukraine. On the contrary, up to now, there is a stereotype and prejudice against these professions and those receiving services. Moreover, data from our research suggest that transition to civilian life for ex-combatants is undermined by inadequate procedures, lack of support and too complicated administrative demands.

Our findings are in line with the other research conducted in Ukraine in 2019 [12]. The survey highlighted that veterans feel excluded from society and have a strong sense of selfidentification with their reference group. A high share of respondents supported the idea that the veterans' experience can be understood only by those who are at least somehow connected to individuals with a military background. It was found that the veterans were more reluctant to consider themselves in need of psycho-social support. However, one-third of the respondents indicated that they would like to receive at least one of the suggested types of psycho-social support, such as individual counselling with a psychologist or consultation with a psychologist who has experience in military service. Veterans also mentioned that the ex-combatants might neglect psychological support because they do not want to show their problems.

The other research of challenges experienced by ATO veterans' families [6] uncovered the main problems of these families, e.g., psychological, financial, legal, and problems with raising children.

So, we can see from our and other research findings that the protection frameworks for excombatants and social reintegration services are not working correctly in Ukraine.

\section{DISCUSSIONS}

Based on in-depth interviews and further analysis, different categories of problems experienced by the Ukrainian ex-combatants have been identified. The study showed that the primary need of the ATO (OOS) participant after returning home is social and psychological support. ATO participants say they have high expectations for the family and society, not from the state. However, some of them face ambivalent and hostile attitudes. While Ukrainian social workers are not trained to provide social services for excombatants, their families, people with PTSD, professional social work is undeveloped [23]. Besides, there are long-standing social welfare traditions and thus paternalistic expectations both from ex-combatants and broader societal groups that the state is obliged to provide social guarantees and benefits.

To develop an adequate response to uncovered problems, the military social work concepts and ideas on employment among military veterans $[5 ; 9 ; 20]$ could help deal with the armed conflict aftermath and strengthen its response. Furthermore, social participation and inclusion of excombatants concerning the DDR concept $[11 ; 28]$ and resilience-based approach [3] should be a core idea of social work approach instead of paternalistic social welfare approaches inherited by 
Ukraine from the Soviet model of social assistance. At the same time, Ukrainian social workers consider the recent research results on masculinity [24] and to contrast gender role norms that prevent them from seeking psychological and social help, consider how traditional masculine role narratives may influence the experience of reintegration challenges.

In Ukraine, there is a shortage of social workers who would have developed skills and in-depth knowledge of cooperation with combatants or those affected by the armed conflict [23; 22]. Specialised training should be introduced to have highly skilled social workers in each area, city and community. The curriculum must include learning the specifics of ex-combatants to a peaceful life and the features of a family-oriented approach to working with family members of service members.

Several Ukrainian publications [13, 25] recommend forming social workers' willingness to work with PTSD and suggest that educational programmes for students should have a specific focus on dealing with war trauma experience. But our study shows other, broader needs and expectations of combatants. Both experts and excombatants themselves believe that support from a social worker and a psychologist should be obtained. Further research could be aimed at looking at the ex-combatants distress and the contextualised ways to tackle it. This would help social workers and psychologists to apply adequate interventions. As classical DDR concept (Disarmament -Demobilisation - Reintegration) doesn't work in Ukraine due to the hybrid nature of the armed conflict.

Based on the study of core needs and practice of rendering services to ex-combatants in Ukraine, analysis of the activities of the Lviv Center for providing services to combatants and the Center for assistance to ATO participants and their families (Dnipro), familiarisation with the basic methods of work with participants of hostilities, we can recommend amending the current state program of physical, medical, psychological rehabilitation and re-adaptation of ATO participants. The changes to the program might include the introduction of social and psychological support to be provided by all centres and services for ATO veterans. In addition, other amendments to the program should include the following:

- collaboration between a social worker and a psychologist with an ATO participant who has just returned from the war zone;
- providing social workers with information and counselling on benefits, subsidies, cash payments and other opportunities provided by the legislation of Ukraine;

- regular meetings with a social worker and a psychologist; visits of the social worker to the family where the war veteran resides;

- reports on possible projects targeted at combatants;

- spending time in a recreation or health centre with a family or in solitude. Financing - state, local, in addition, the participants of ATO (OOS) will be encouraged to make partial payment;

- after vacations, consultations on professional activity: adaptation to the previous place of work, retraining, opportunities to search at the Employment Center; the list of NGOs, charity funds, state institutions that are interested in cooperation with the ATO participants.

The pre-deployment psycho-social support to combatants and their families would also be an asset in preparing military personnel for battlefield situations, strengthening resilience.

All in all, the relevant model of social reintegration services for ex-combatants should be built on the community level. Since most of them trust mainly their comrades in arms, it may be better to teach social work war veterans and employ a grass-root peer-to-peer approach, but with relevant professional competencies. The critical directions for developing the protective framework for ex-combatants in Ukraine are summarised in Figure 1.

We appreciate the limitations of our small-scale qualitative study designed to investigate the phenomenon of social support to ex-combatants by understanding respondents' lived experiences, as the social situation in Ukraine is rather dynamic and evolving, even today. The other ethically sensitive issue is researchers' empathy to ex-combatants. The close distance between researchers and other study participants is viewed as 'normal' in social work and standing for social justice [8]. Yet, we still have hesitations about the 'lenses' we have while conducting interpretations. So, we believe that our research will add value to those arguments favouring making the protection frameworks for ex-combatants and social reintegration services more efficient and accessible. 
Legislation and regulatory framework for professional activity

Amendments to the legislation, development of a standard of social and psychological assistance to veterans and their families

Development of interdepartmental interaction

Development of effective mechanisms for joint actions of institutions subordinated to the Ministry of Defense, the Ministry of Health, the Ministry of Social Policy

\section{Improving the professional competence of social workers}

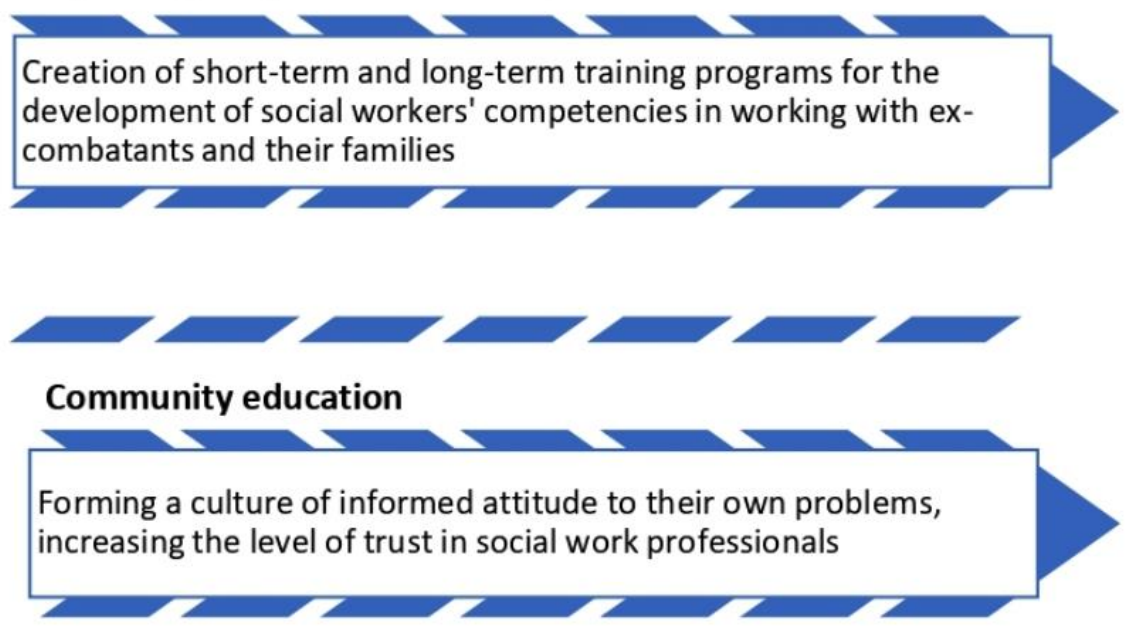

Support for user group initiatives, volunteer training

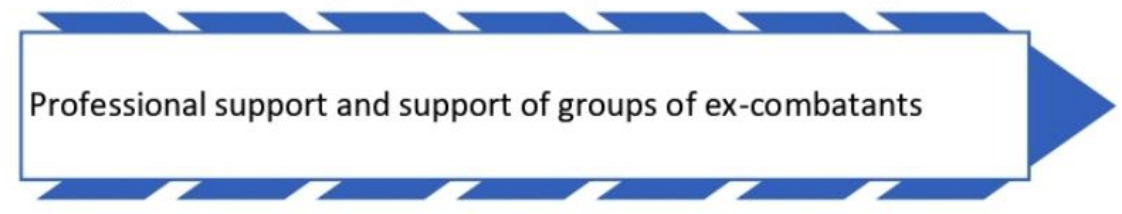

Working with families

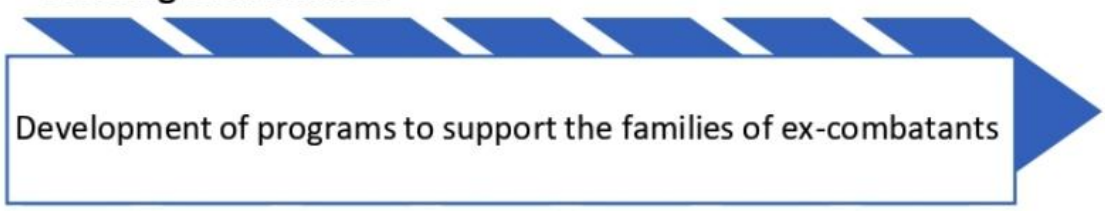

Figure 1 - The key directions for the development of the protective framework for ex-combatants in Ukraine

Notes: The figure was produced by authors based on the research findings and discussions of the existing literature

\section{CONCLUSIONS}

The interviews with Ukrainian ex-combatants and experts made it possible to identify the basic needs and requests that a demobilised soldier faces in adapting to a peaceful life. The study showed that the primary need of an ATO participant after returning home is social and psychological support. ATO veterans said they have high expectations for the family and society, as op- posed to the state. Respondents considered that a prerequisite for returning home is respect and gratitude, understanding of the experience.

The findings indicate pitfalls in the protective framework of war veterans. Currently, the available social support comes down to material benefits: benefits, subsidies, cash payments and more. In addition, respondents pointed out the need to develop comprehensive social work in- 
terventions for combatants. This paper concludes that more needs to be done to enhance the social services for the new group of social work clients, including services that could enable excombatants to develop the skills they need to reintegrate within their community.

\section{REFERENCES}

1. Boiarska, Z., \& Pinchuk, R. (2018). Dynamics of anxiety of participants of united forces operation. ScienceRise: Biological Science, 5(14), 22-26. doi: 10.15587/2519-8025.2018.146930

2. Brickell, M., Russell, M. C., \& Smith, R. B. (2015). The Effectiveness of Evidence-Based Treatments in Treatment of Active Military Personnel and Their Families. Journal of EMDR Practice and Research, 9(4), 198-208. doi: 10.1891/1933-3196.9.4.198

3. Council on Social Work Education. (2010). Advanced social work practice in military social work. Retrieved from https://cswe.org/getattachment/Accreditation/Other/EPASImplementation/Advanced_Social_Work_Practice_in_Military_Social_Work_2010.pdf.aspx\#: :te $\mathrm{xt}=$ Advanced $\% 20$ practitioners $\% 20 \mathrm{in} \% 20$ military $\% 20$ social,for $\% 20$ the $\% 20$ diverse $\% 20$ service $\% 20$ member

4. Crock, M., Hart, N. \& McCallum, R. (2014). War, law and disability: Ensuring equality in situations of crisis. In D. Mitchell, \& V. Karr (Eds.), Crises, Conflict and Disability: Ensuring equality (pp. 9-18). Abingdon: Routledge, Taylor \& Francis Group.

5. Derzhavna tsilova prohrama z medychnoi, fizychnoi reabilitatsii ta psykhosotsialnoi readaptatsii postrazhdalykh uchasnykiv Revoliutsii Hidnosti, uchasnykiv antyterorystychnoi operatsii ta osib, yaki braly uchast u zdiisnenni zakhodiv iz zabezpechennia natsionalnoi bezpeky i oborony, vidsichi i strymuvannia zbroinoi ahresii Rosiiskoi Federatsii v Donetskii ta Luhanskii oblastiakh, zabezpechenni yikh zdiisnennia, na period do 2023 roku [State target program on medical, physical rehabilitation and psychosocial readaptation of victims of the Revolution of Dignity, participants of the anti-terrorist operation and persons who took part in measures to ensure national security and defense, repel and deter armed aggression of the Russian Federation in Donetsk and Luhansk regions, implementation, for the period up to 2023] (Ukraine), 05.12.2018, No 1021. Retrieved May 1, 2021, from https://zakon.rada.gov.ua/laws/show/10212018-\%D0\%BF\#Text (in Ukrainian)

[Державна цільова програма з медичної, фізичної реабілітації та психосоціальної реадаптації постраждалих учасників Революції Гідності, учасників антитерористичної операції та осіб, які брали участь у здійсненні заходів із забезпечення національної безпеки і оборони, відсічі і стримування збройної агресії Російської Федерації в Донецькій та Луганській областях, забезпеченні їх здійснення, на період до 2023 року (Україна), 05.12.2018, № 1021. Актуально на 01.05.2021. URL: https://zakon.rada.gov.ua/laws/show/1021-2018-\%D0\%BF\#Text].

6. Dulia, A., Liakh, T., \& Veretenko, T. (2019). The Problems and Needs of the Families of Antiterrorist Operation Participants: Results of In-depth Interviews. The New Educational Review, 55(1), 220230. doi: 10.15804/tner.2019.55.1.18

7. Edward, K.-L., \& Welch, T. (2011). The extension of Colaizzi's method of phenomenological enquiry. Contemporary Nurse, 39(2), 163-171. doi: 10.5172/conu.2011.163

8. Eriksson, K., \& Englander, M. (2017). Empathy in Social Work. Journal of Social Work Education, 53(4), 607-621. doi: 10.1080/10437797.2017.1284629

9. Griffin, Jr., C. L., \& Stein, M. A. (2015). Self-perception of disability and prospects for employment among U.S. veterans. Work, 50(1), 49-58. doi: 10.3233/wor-141929

10. Horbulin, V. (Ed.) (2017). The World Hybrid War: Ukrainian Forefront. Kyiv: Folio.

11. International Labour Office. (2009). Socio-Economic Integration of Ex-Combatants. Retrieved from https://www.ilo.org/wcmsp5/groups/public/@ed_emp/documents/instructionalmaterial/wc ms_141276.pdf 
12. International Organisation for Migration. (2020, January). Life after conflict: survey on the sociodemographic and socioeconomic characteristics of veterans of the conflict in eastern Ukraine and their families. Retrieved from http://ukraine.iom.int/sites/default/files/veterans_reintegration_survey_2020_eng.pdf

13. Kharchenko, O., \& Mramornova, O. (2016). Problemy veteraniv antyterorystychnoi operatsii na skhodi Ukrainy [Problems of veterans of the anti-terrorist operation in eastern Ukraine]. Visnyk Kharkivskoho natsionalnoho universytetu imeni V. N. Karazina. Seriia: Sotsiolohichni doslidzhennia suchasnoho suspilstva: metodolohiia, teoriia, metody, 37, 115-124 (in Ukrainian) [Харченко, О., \& Мраморнова, О. (2016). Проблеми ветеранів антитерористичної операції на сході України. Вісник Харківського національного університету імені В. Н. Каразіна. Серія: Соціологічні дослідження сучасного суспільства: методологія, теорія, методи, 37, 115-124].

14. Lamichhane, K. (2015). Social inclusion of people with disabilities: a case from Nepal's decade-long civil war. Scandinavian Journal of Disability Research, 17(4), 287-299. doi: 10.1080/15017419.2013.861866.

15. Laverty, S. M. (2003). Hermeneutic Phenomenology and Phenomenology: A Comparison of Historical and Methodological Considerations. International Journal of Qualitative Methods, 2(3), 21-35. doi: 10.1177/160940690300200303

16. Ministry of Veterans Affairs, Temporarily Occupied Territories and Internally Displaced Persons of Ukraine. (2019). Information on granting combatant status. Retrieved from:

http://dsvv.gov.ua/dostup-do-publichnoji-informatsiji/informatsiya-schodo-nadannya-statusuuchasnyka-bojovyh-dij.html

17. Molendijk, T., Kramer, E.-H., \& Verweij, D. (2015). Conflicting Notions on Violence and PTSD in the Military: Institutional and Personal Narratives of Combat-Related Illness. Culture, Medicine, and Psychiatry, 40(3), 338-360. doi: 10.1007/s11013-015-9469-0

18. Morrow, R., Rodriguez, A. \& King, N. (2015). Colaizzi's descriptive phenomenological method. The Psychologist, 28(8), 643-644.

19. Pascal, J. (2010). Phenomenology as a Research Method for Social Work Contexts: Understanding the Lived Experience of Cancer Survival. Currents: New Scholarship in the Human Services, 9(2), $1-23$.

20. Pro status veteraniv viiny, harantii yikh sotsialnoho zakhystu [About the status of war veterans, guarantees of their social protection] (Ukraine), 22.10.1993, No 3551-XII. Retrieved May 1, 2021, from https://zakon.rada.gov.ua/laws/show/3551-12\#Text (in Ukrainian)

Про статус ветеранів війни, гарантії їх соціального захисту (Україна), 22.10.1993, № 3551XII. Актуально на 01.05.2021. URL: https://zakon.rada.gov.ua/laws/show/3551-12\#Text

21. Rubin, A., Weiss, E. L. \& Coll, J. E. (2013). Handbook of Military Social Work. Hoboken: John Wiley \& Sons.

22. Semigina, T. (2017). Frustrations or moving forward? Ukrainian social work within the "hybrid war" context. European Journal of Social Work, 22(3), 446-457. doi:

10.1080/13691457.2017.1366432

23. Semigina, T. (2018). Human-made Disasters and Social Work: A Ukrainian Prospective. In L. Dominelly (Ed.), The Routledge Handbook of Green Social Work (p. 431-441). Abingdon: Routledge.

24. Shields, D., \& Westwood, M. (2019). Counselling and Veterans: Addressing Challenges and Enhancing. The Palgrave Handbook of Male Psychology and Mental Health, 417-438. doi: 10.1007/978-3-030-04384-1_21

25. Surmiak, Yu., \& Kudryk, L. (2015). Sotsialno-psykholohichna dopomoha uchasnykam boiovykh dii u podolanni posttravmatychnoho stresovoho rozladu [Social and Psychological Assistance to Participants of Hostilities in Overcoming Post-traumatic Stress Disorder]. Pedahohika $i$ 
psykholohiia profesiinoi osvity, 3, 123-134 (in Ukrainian)

[Сурмяк, Ю., \& Кудрик, Л. (2015). Соціально-психологічна допомога учасникам бойових дій у подоланні посттравматичного стресового розладу. Педагогіка і психологія професійної освіти, 3, 123-134].

26. Terziev, V. (2019). Analysis of the Bulgarian Experience in the Development of the Social Adaptation of Servicemen, Discharged From Military Service. SSRN Electronic Journal. doi: 10.2139/ssrn.3384673

27. United Nations. (2018, December 4). Global Humanitarian Overview 2019 - Trends in Humanitarian Needs and Assistance. Retrieved from https://reliefweb.int/sites/reliefweb.int/files/resources/Trends\%20in\%20Humanitarian\%20 Needs\%20and\%20Assistance\%20Factsheet.pdf

28. Velardea R., Diaz, K., \& Shakespeare, T. (2019). Social participation and inclusion of ex-combatants with disabilities in Colombia. Disability and the Global South, 6(2), 1736-1755.

29. Vermetten, E., Greenberg, N., Boeschoten, M. A., Delahaije, R., Jetly, R., Castro, C. A., \& McFarlane, A. C. (2014). Deployment-related mental health support: comparative analysis of NATO and allied ISAF partners. European Journal of Psychotraumatology, 5(1), 23732. doi: 10.3402/ejpt.v5.23732

30. World Bank. (2017, May). Conflict in Ukraine. Socio-economic impacts of internal displacement and veteran return - Summary Report. Retrieved from https://documents1.worldbank.org/curated/en/571011497962214803/pdf/116489REVISED-Updated-Report-Socioeconomic-Impacts-Internal-Displacement-VeteranRet.pdf?dLDf=false 